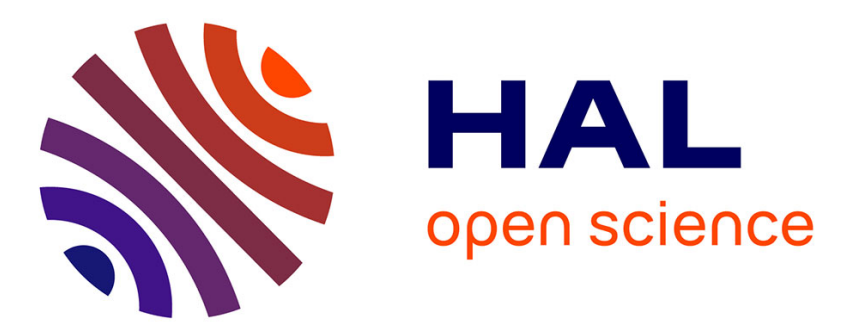

\title{
A seasonal deuterium excess signal at Law Dome, coastal eastern Antarctica: A southern ocean signature
}

Marc Delmotte, Valérie Masson, Jean Jouzel, Vin Morgan

\section{To cite this version:}

Marc Delmotte, Valérie Masson, Jean Jouzel, Vin Morgan. A seasonal deuterium excess signal at Law Dome, coastal eastern Antarctica: A southern ocean signature. Journal of Geophysical Research: Atmospheres, 2000, 105 (D6), pp.7187-7197. 10.1029/1999JD901085 . hal-03103023

\section{HAL Id: hal-03103023 https://hal.science/hal-03103023}

Submitted on 11 Jan 2021

HAL is a multi-disciplinary open access archive for the deposit and dissemination of scientific research documents, whether they are published or not. The documents may come from teaching and research institutions in France or abroad, or from public or private research centers.
L'archive ouverte pluridisciplinaire HAL, est destinée au dépôt et à la diffusion de documents scientifiques de niveau recherche, publiés ou non, émanant des établissements d'enseignement et de recherche français ou étrangers, des laboratoires publics ou privés. 


\title{
A seasonal deuterium excess signal at Law Dome, coastal eastern Antarctica: A southern ocean signature
}

\author{
Marc Delmotte,' Valérie Masson, and Jean Jouzel \\ Laboratoire des Sciences du Climat et de l'Environnement (LSCE), UMR CEA-CNRS. Gil-sur-Yvette, France
}

Vin I. Morgan

Antarctic CRC and Australian Antarctic Division, Hobarh, Australia.

\begin{abstract}
The snow isotopic composition $\left(\delta^{1 k} \mathrm{O}\right.$ and $\left.\delta \mathrm{D}\right)$ of two shallow cores from the high accumulation summit region of Law Dome, east Antarctica, was measured at monthly resolution over the 1980-1992 period. While the $\delta^{18} \mathrm{O}$ or $\delta \mathrm{D}$ signals clearly reflect the local temperature cycle, the deuterium excess $\left(d=\delta \mathrm{D}-8 \delta^{18} \mathrm{O}\right)$ is shifted with respect to $\delta^{18} \mathrm{O}$ cycle by a 4 months lag. Interpretation of this phase lag is investigated using both an Atmospheric General Circulation Model (AGCM), which includes the water isotopic cycles, and a simple isotopic model, which better describes the microphysical processes within the cloud. Using this dual approach, we show that the seasonality of $\delta^{1 \mathrm{O}} \mathrm{O}$ and $d$ at Law Dome summit results from a combination of the southern ocean temperature cycle (shifted by 2-3 months with respect to the local insolation) and seasonal moisture origin changes due to a strong contribution of the local ocean when ice free. Both approaches are consistent with a dominant temperate to subtropical moisture origin. We thus demonstrate from our present-day subseasonal study that the record of $d$ in the Dome Summit South (DSS) deep ice core represents a potential tool for identifying changes in Southern Ocean temperatures and/or sea ice cover at the scale of the past thousand years.
\end{abstract}

\section{Introduction}

\subsection{Deuterium Excess Parameter}

The water isotopic composition $\left(\delta^{18} O\right.$ or $\delta \mathrm{D}$ expressed as per mil deviation versus Standard Mean Ocean Water (SMOW)) measured in ice cores is commonly used to infer paleoclimatic information such as temperature and accumulation [Ciais et al., 1994; Cuffey and Clow, 1997; Jouzel et al., 1987a, 1996]. The combination of both isotopic species enables the investigation of a second-order parameter. the deuterium excess (d) defined by the following expression [Dansgaard, 1964]

$$
d=\delta \mathrm{D}-8 * \delta^{1 \mathrm{t}} \mathrm{O}
$$

The deuterium excess parameter reflects the different behaviors of the two isotopic species (HDO and $\mathrm{H}_{2}{ }^{18} \mathrm{O}$ ) occurring during processes such as Rayleigh-type equilibrium fractionation. The deuterium excess is also sensitive to nonRayleigh phase changes, such as the evaporation from the ocean or the formation of ice crystals inside a cloud. During these specific phase changes, the water isotopic molecules undergo an additional nonequilibrium fractionation ("kinetic effect" as described by Merlivat and Jouzel [1979]) resulting from differences in the diffusion coefficients of the different molecules. The kinetic fractionation enhances the differences between the fractionation of $\mathrm{HDO}$ and $\mathrm{H}_{2}{ }^{18} \mathrm{O}$ and thereby plays

'Now at Laboratoire de Géochimie et Cosmochimie, CNRS/IPGP, Paris, France.

Copyright 2000 by the American Geophysical Union.

Paper number 1999JD901085.

0148-0227/00/1999JD901085\$09.00 a large role in determining the $d$ composition of the polar precipitation.

Interpretation of polar snow deuterium excess using simple isotopic models has shown that $d$ is strongly dependent on the sea surface temperature (SST), relative humidity, and surface wind speed of the oceanic moisture source [Ciais et al., 1995; Johnsen et al., 1989; Jouzel and Merlivat, 1984; Petit et al., 1991]. The combination of measured and simulated $\left(\delta^{18} \mathrm{O}, d\right)$ data is thus a potential tool for the identification of major characteristics of moisture sources contributing to Antarctic precipitation [Ciais et al., 1995; Petit et al., 1991]. In this paper this approach will be applied on a subseasonal timescale for the specific Law Dome area.

\subsection{Law Dome Site}

For more than 20 years, glaciological and climatological research programs have been conducted by the Australian National Antarctic Research Expeditions (ANARE) in Wilkes Land, eastern Antarctica. A particular interest has been devoted to the Law Dome area, where several ice drillings were performed [Budd and Morgan, 1977; Budd, 1966; Morgan, 1979, 1985], including a recent deep drilling down to the bedrock at the Dome Summit South (DSS) site near the summit of the dome [Morgan et al., 1997].

Law Dome is a small ice cap about $200 \mathrm{~km}$ in diameter located on the coast of East Antarctica at $66^{\circ} 46^{\prime} \mathrm{S}$ latitude, $112^{\circ} 48^{\prime} \mathrm{E}$ longitude. The Law Dome summit area $(1390 \mathrm{~m}$ above sea level) gathers favorable conditions for isotopic studies because of its (1) low mean annual temperature $\left(-22^{\circ} \mathrm{C}\right)$ preventing summer melting, (2) large accumulation rate $\left(640 \mathrm{~kg} \mathrm{~m}^{-2} \mathrm{yr}^{-1}, 0.7 \mathrm{~m}\right.$ of ice equivalent per year) providing an excellent temporal resolution, (3) moderate mean annual 
surface wind speed $\left(8.3 \mathrm{~m} \mathrm{~s}^{-1}\right)$ and a small horizontal flow at the summit of the dome $\left(<1 \mathrm{~m} \mathrm{an}^{-1}\right)$ excluding large disturbances in snow stratigraphy.

All these conditions enable the preservation of well-marked seasonal cycles in the ice isotopic composition as well as other seasonal species [Delmotte et al., 1999; Van Ommen and Morgan, 1996]. The existence of these cycles also provides a tool to date the cores by counting the individual seasonal cycles.

In this paper we use $\delta^{18} \mathrm{O}$ and $\delta \mathrm{D}$ data measured in two firn cores drilled near DSS at the summit of Law Dome to study the deuterium excess parameter on a subseasonal timescale, with the aim of characterizing the oceanic moisture source for the Law Dome area. The observed isotopic seasonal cycles are interpreted using both an atmospheric general circulation model, including the water isotopic cycles, and a simple isotopic model. This work represents a first-step analysis to the interpretation of the full DSS deep ice core deuterium excess profile [Delmotte, 1997] which covers the last 10,000 years with a high resolution during the early Holocene period.

\section{Observations}

\subsection{Measurements and Age Scale:}

Our study is based on more than 800 individual isotopic analyses $\left(\delta \mathrm{D}\right.$ and $\left.\delta^{18} \mathrm{O}\right)$ conducted on two shallow firn cores located in the vicinity of the DSS deep drilling. The first core (DSS 87P) was drilled in December 1987. $2 \mathrm{~m}$ away from the main DSS core. It is $12.4 \mathrm{~m}$ long and was sampled regularly each $5 \mathrm{~cm}$. To complement this and extend the record, a second core (DSS 92P) was drilled in January 1992, $200 \mathrm{~m}$ southwest of DSS 87P. For this $9.6 \mathrm{~m}$ long core, a different sampling method was adopted; in order to have a regular temporal sampling, $7 \mathrm{~cm}$ samples were taken from zero to $2.72 \mathrm{~m}$ depth, then $6 \mathrm{~cm}$ samples from 2.72 to $8.01 \mathrm{~m}$, and finally, $5 \mathrm{~cm}$ samples from 8.01 down to the bottom of the core. Each sample was measured for $\delta^{18} \mathrm{O}$ and $\delta \mathrm{D}$ at Laboratoire des Sciences du Climat et de l'Environnement (LSCE) with a high precision: $0.5 \%$ and $0.05 \% \circ$ for $\delta \mathrm{D}$ [Vaughn et al., 1998] and $\delta^{1 x} \mathrm{O}$ [Delmotte, 1997] respectively, leading to an accuracy of $0.7 \%$ for $d$. There is a good agreement between the $\delta^{18} \mathrm{O}$ measured in the two cores in the overlapping section during the period 1986-1988 (see Figure 1), confirming the minimal disturbance of the layering by surface snow redistribution.

The very clear seasonal cycles revealed by the isotopic records (see Figure 1) enable a yearly dating, to be produced by counting the seasonal cycles in $\delta^{18} O$ (or $\delta D$ ). Furthermore, the use of the $\mathrm{HO}$ record [Van Ommen and Morgan, 1996] provides a precise dating at a monthly resolution because of the strong dependency of this signal to the intensity and spectral distribution of the solar radiation [Neftel et al., 1986, 1995]. On the basis of this hypothesis, Van Ommen and Morgan [1996] associated the highest values of peroxide with the summer solstice. The time lag between the maxima of peroxide and the maxima of the ice isotopic composition places the isotopic maximum around mid-January, in accordance with the temperature maximum from local meteorological data [Russell-Head and Simmonds, 1993]. The temporal resolution of our records covers a minimum of two

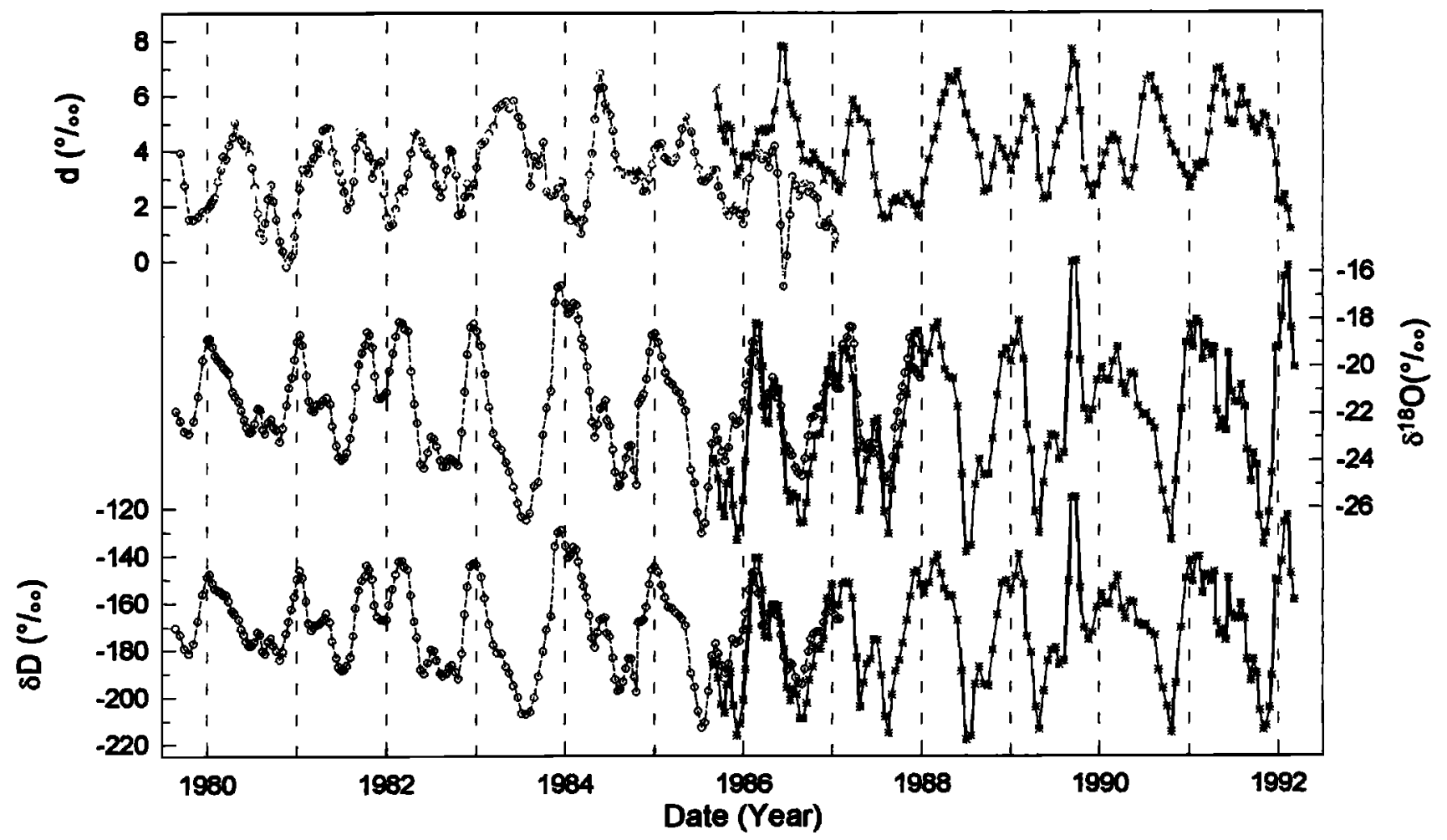

Figure 1. Isotopic records $\left(\delta^{18} \mathrm{O}, \delta \mathrm{D}\right.$, and $d$ ) obtained from the DSS shallow cores. The circles represent the results from the Dome Summit South (DSS) PICO 1987 and the asterisks illustrate the results obtained from the DSS PICO 1992. The excess record has been smoothed using a running average over three points to reduce the high-frequency variability. The upper $1.65 \mathrm{~m}$ of the DSS P87 core was not measured for deuterium (i.e., excess) as there were no samples left after $\delta^{18} \mathrm{O}$ measurements. 


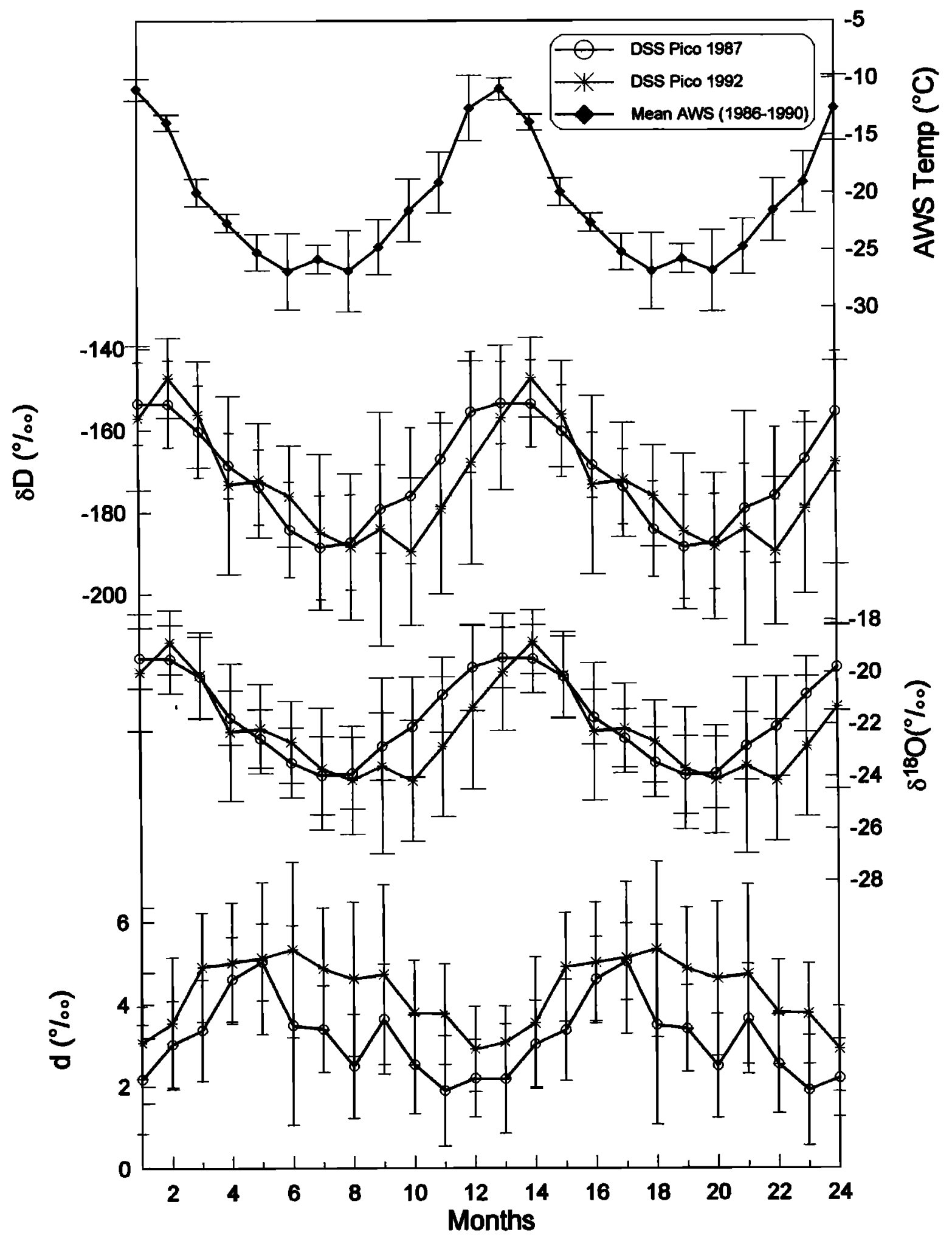

Figure 2. Mean seasonal cycles of $\delta \mathrm{D}, \delta^{18} \mathrm{O}$, and $d$ (bottom curves) at DSS deduced from both firn cores, as a function of months. The top curve represents the mean annual temperature record over the 1986-1990 period obtained from the automatic weather station (AWS) of DSS (I. Allison, personal communication, 1997). In all cases the yearly cycle has been represented twice for clarity, and the error bars indicate the interannual standard deviation $(1 \sigma)$. 
samples per month. A direct comparison of the isotopic records of the two cores with the meteorological data from the Law Dome automatic weather station (AWS) (available for the 1991-1996 period, see Figure 2) shows good correlation between the ice core data and the local temperature and confirms the validity of the dating method used.

\subsection{Results}

The isotopic records $\left(\delta^{18} \mathrm{O}, \delta \mathrm{D}\right.$, and $\left.d\right)$ are shown in Figure 1. Note that the $d$ record is presented as a running mean average over three points, in order to reduce the highfrequency variability. Well-markèd seasonal cycles appear in the $\delta \mathrm{D}, \delta^{1 \mathrm{k}} \mathrm{O}$, and the $d$ records. There is a small offset $(1.2 \%$ o $)$ between the two excess records resulting from similar shifts in $\delta^{1 \times} \mathrm{O}(0.5 \% o)$ and $\delta \mathrm{D}(2.6 \%)$ records. Such differences between adjacent cores are typical of isotopic deposition and arises from modulation of the accumulation by the surface roughness and by post deposition processes [White et al., 1997]. The $\delta^{1 x} \mathrm{O}$ shift observed at Law Dome is quantitatively in good agreement with the observations from the Arctic [Fisher et al., 1985]. Law Dome region is characterized by very large gradients in elevation and accumulation rate. However, unlike each isotopic specie (sensitive to elevation change), the deuterium excess is fairly constant all over the Law Dome area, as indicated by measurements from several firn and ice cores representative of the large range of elevation and accumulation rates encountered in this region (Table 1). This result enables us to rule out the possibility of a geographical drift responsible for the $d$ shift.

The mean amplitude of $d$ as calculated from the raw data generally averages at $5 \%$ but occasionally reaches values as high as $8 \%$ (similar to the amplitude in $\delta^{14} \mathrm{O}$ ). The amplitude of the seasonal signals is fairly constant with depth, since the isotopic smoothing due to water vapor diffusion in the firn (diffusion length of $8 \mathrm{~cm}$ [Van Ommen and Morgan, 1996]) has minimal effect because of the large accumulation. The good overlapping of the two cores between 1986 and 1988, corresponding, respectively, to the bottom and to the upper part of the 1992 and 1987 firn cores corroborates this minimum isotopic smoothing effect. The large opposite excess spikes revealed by the two cores between 1986 and 1987 remain unexplained, but the measurements have been checked and are not in question. It is possibly linked with the very low density at the top of DSS 87P.

Using a time normalization of the average isotopic signals [Cicis et al., 1995] enables us to look carefully at the phase relationship between $\delta^{1 x} \mathrm{O}$ and $d$. The average seasonal cycles of $\delta \mathrm{D}$ and $\delta^{\mathrm{ix}} \mathrm{O}$ (see Figure 2 ) clearly reflect the seasonality of the local surface air temperature, with an isotopic minimum in winter (July-August) and an isotopic maximum during summer (January-February). The seasonality of $d$ is shifted by 4 months ( \pm 1 month as illustrated in Figure 2), with a minimum in late spring (November-December) and a maximum occurring most frequently in late autumn (May-June). Using either the raw $d$ data or the smoothed profile does not affect this result. Interestingly, the phase relationship seems remarkably stable in time during the late Holocene, as revealed by individual seasonal cycles measured in the DSS deep ice core at various depths $(200,400,600$, and $900 \mathrm{~m}$ covering the last 5000 years, not shown).

In a previous study Johnsen and White [1989] examined data from Greenland and showed that at low altitudes $d$ and $\delta^{1 \mathrm{~B}} \mathrm{O}$ were in phase opposition, while at higher elevations, there

Table 1. Geographic Distribution of Deuterium Excess Over the Law Dome Ice Cap As Inferred From Several Firn and Ice Cores.

\begin{tabular}{|c|c|c|c|c|c|c|c|c|c|c|}
\hline \multirow[b]{2}{*}{ Site } & \multicolumn{5}{|c|}{ Location } & \multirow{2}{*}{$\begin{array}{l}\text { Time Period } \\
\text { Covered or } \\
\text { Number of } \\
\text { Measurements }\end{array}$} & \multirow[b]{2}{*}{ Resolution ${ }^{h}$} & \multirow{2}{*}{$\begin{array}{l}\delta \mathrm{D} \\
(\% \circ)\end{array}$} & \multirow{2}{*}{$\begin{array}{l}\delta^{14} \mathrm{O} \\
(\% c)\end{array}$} & \multirow{2}{*}{$\begin{array}{l}d \\
(\% o)\end{array}$} \\
\hline & Latitude & Longitude & $\begin{array}{l}\text { Elevation } \\
\text { (m) }\end{array}$ & $\begin{array}{l}\text { Accumulation } \\
\left(\mathrm{kg} \mathrm{m}^{-2} \mathrm{yr}^{-1}\right)\end{array}$ & $\begin{array}{l}\text { Dome } \\
\text { Location }\end{array}$ & & & & & \\
\hline DSS 87P & $66^{\circ} 46^{\prime} 11^{\prime \prime}$ & $112^{\circ} 48^{\prime} 25^{\prime \prime}$ & 1379 & 640 & Summit & $1979-1987$ & SS & -170.3 & -21.67 & $31^{14}$ \\
\hline DSS 92P & $66^{\circ} 46^{\prime} 16^{\prime \prime}$ & $112^{\circ} 48^{\prime} 25^{\prime \prime}$ & 1.379 & 640 & Surnmit & $198.5-1992$ & SS & -172.9 & -22.15 & 4.3 \\
\hline DSS deep & $66^{\circ} 46^{\circ} 11 "$ & $112^{\circ} 48^{\circ} 25^{\prime \prime}$ & 1379 & 640 & Summit & $1742-1842^{\prime \prime}$ & A & -175.2 & -22.39 & 3.9 \\
\hline DEO8-2 & $66^{\circ} 43^{\prime} 26^{\prime \prime}$ & $112^{\circ} 48^{\prime} 25^{\prime \prime}$ & 1270 & 1144 & eastern flank & $1979-1992$ & SS & -1590 & -20.49 & 5.2 \\
\hline $\mathrm{BHF}$ & $66^{\circ} 09^{\prime} 06^{\prime \prime}$ & $112^{\circ} 48^{\prime} 25^{\prime \prime}$ & 360 & 80 & $\begin{array}{l}\text { north west } \\
\text { coast }\end{array}$ & 113 points & $?$ & -144.1 & -18.62 & 4.9 \\
\hline
\end{tabular}

"No deuterium measurements were made on the upper part of the DSS deep ice core (bad ice quality) and we then used the first I00 years of the isotopic records to calculate the mean values presented here.

"The resolution of the DSS deep ice core is annual (A) whereas for DEO8-2 and the two firn cores it is subseasonal (SS). Due to the important flow disturbances at BHF, no precise timescale was established for this record [Budd and Morgan, 1977l. It is therefore difficult to assess the resolution of this record, but the isotopic values for BHF arise from means of 7 core sections from the Holocene period (core sections are 1.5 to $1.7 \mathrm{~m}$ long with a $10 \mathrm{~cm}$ sampling resolution).

$r$ The experimental uncertainties for $\delta \mathrm{D}$ and $\delta^{18} \mathrm{O}$ measurements are 0.5 and $0.05 \%$, respectively, except for BHF (0.15\%o for $\left.\delta^{18} \mathrm{O}\right)$. This leads to an uncertainty of $\pm 0.7 \%$ for all $d$ determination, except for BHF $( \pm 1.3 \%$ ). We have also estimated the temporal variability of $d$ to be $\sim 0.6 \%$ by applying a 13 year average window to the first 150 years of the DSS deep $d$ record.

"Without taking into account the deuterium excess points from the upper part of the DSS 87P (negative spike), the mean excess value would be 3.2 instead of 3.1 . 
was a lag in d. Ciais and others [1995] reported on the phasing of $d$ and $\delta \mathrm{D}$ at South Pole and D47 in Terre Adelie. They found that at $\mathrm{D} 47, d$ was in phase with $\delta \mathrm{D}$, while at South Pole, $d$ lagged $\delta \mathrm{D}$ by $\sim 5$ months. The characteristics of the $\mathrm{D} 47$ $\left(154^{\circ} \mathrm{E}, 75^{\circ} \mathrm{S}\right)$ and DSS sites are quite similar: a short distance from the closest coast (around $100 \mathrm{~km}$ ), a similar elevation (1400 $\mathrm{m}$ for DSS. $1550 \mathrm{~m}$ for D47), and similar average surface temperatures $\left(-22^{\circ} \mathrm{C}\right.$ for DSS and $-25^{\circ} \mathrm{C}$ for $\left.\mathrm{D} 47\right)$. However, our results concerning the $d-\delta \mathrm{D}$ phase lag significantly differ from the one of D47. This difference could be at least partly explained because both the dating and the stratigraphy are less precise at D47, as a result of a smaller accumulation (typically 3 times lower than for DSS) and of the very strong winds (annual average $>11 \mathrm{~m} \mathrm{~s}{ }^{-1}$. [Allison et al., 1993]) which probably significantly alter the snow stratigraphy at that site. Last, one might note that these two coastal sites differ by $10^{\circ}$ In their latitudinal position, Law Dome being further northward and subject to larger maritime influence.

\section{Modeling and Discussion}

To understand the processes responsible for the observed isotopic seasonality at Law Dome, we have used the NASA GISS atmospheric general circulation model (with a horizontal resolution of $8^{\circ}$ by $10^{\circ}$ ), version II [Hansen et al., 1983], in which the water evaporating from various source areas can be tagged [Koster et al., 1986, 1992] and which includes the modeling of water isotopes. A 1979-1988 simulation was performed (the first 2 years of the simulation were considered as spin-up time).

The phase relationship between $\delta^{18} \mathrm{O}$ (or $\delta \mathrm{D}$ ) and $d$ at Law Dome is driven by physical processes affecting phase changes and isotopic fractionations: (1) the seasonal cycle of moisture source meteorological parameters (mainly SST but also relative humidity (h) and wind speed, (w)) which affect the isotopic content of the first evaporated vapor $\left(\delta_{0}\right)$; $(2)$ the seasonal change of moisture source; (3) the trajectory of the moisture and its phase changes history; this includes temperature, supersaturation, condensation, droplet reevaporation. and rain-out history, which are affected by the chemical composition of the atmosphere (aerosols act as cloud condensation nuclei), and the sea ice seasonal variability; and (4) the Law Dome seasonal cycle of condensation temperature and accumulation.

All these processes are fully represented within the atmospheric general circulation model (AGCM) apart from the impact of the atmospheric aerosol load on condensation. Delaygue et al. [1999] have shown that even at this low horizontal resolution, the GISS model captures many features of modern Southern Hemisphere and Antarctic hydrological cycle. Because of the limited horizontal resolution of the model, the area between $70^{\circ} \mathrm{S}$ and $60^{\circ} \mathrm{S}$ latitude, $110^{\circ} \mathrm{E}$ and $120^{\circ} \mathrm{E}$ longitude is considered to be representative of the Law Dome region (two model grid points). We show that despite its low resolution the GISS model is able to simulate realistic seasonal features of Law Dome water isotopes, and we estimate the seasonal change in moisture origin. We then use a simple isotopic model to evaluate the relative impact of moisture source seasonal cycles versus moisture origin seasonal cycle on the excess seasonal cycle. A comparison of the two model analysis procedures used in our study is summarized in Figure 3.

The AGCM-simulated annual mean $\delta^{18} \mathrm{O}$ is slightly too high ( $-19.0 \%$ versus $-21.8 \%$ observed), and the amplitude of the seasonal cycle is overestimated by about one third $(6.4 \%$ versus $4.7 \%$ observed). This is consistent with the simulation
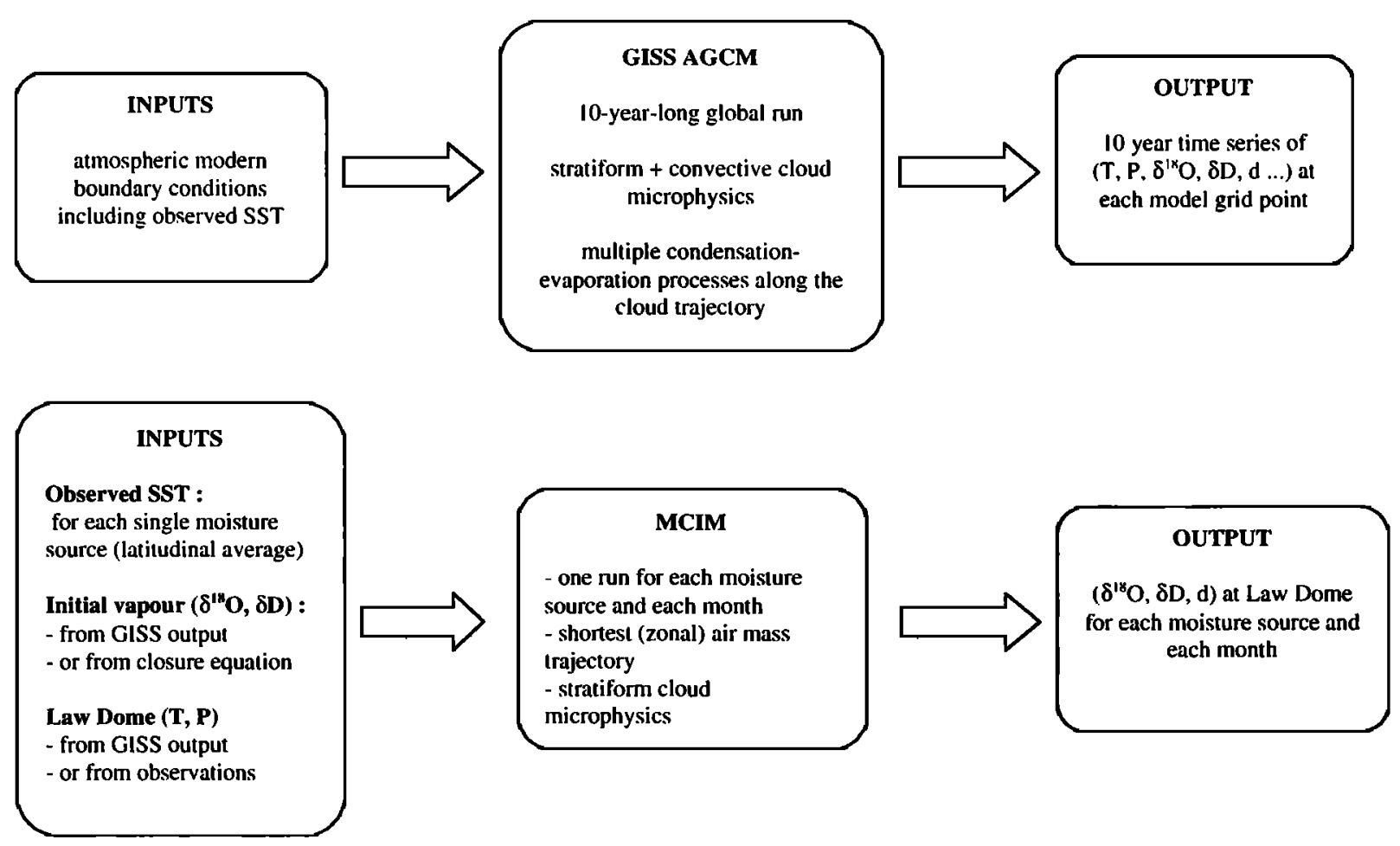

Figure 3. Comparative scheme of the two numerical models used in this study, the GISS AGCM and the simple isotopic model (MCIM). For both models, the main inputs, outputs, and characteristics are presented. 

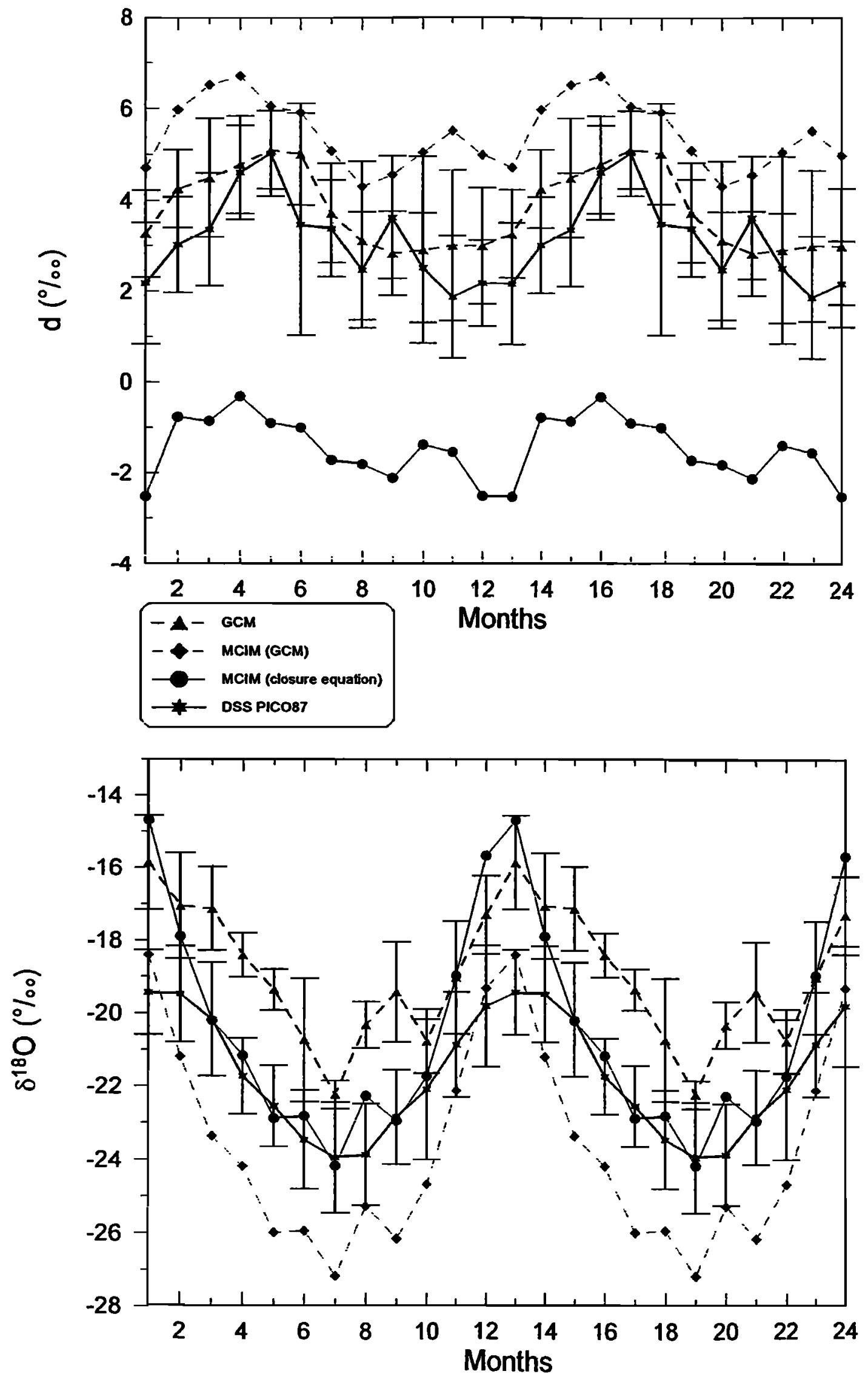

Figure 4. Comparison of the monthly mean $\delta^{18} \mathrm{O}$ and deuterium excess as obtained from the MCIM with the closure equation assumption (mixed origin, circles). from the MCIM with the GISS initialization (mixed origin, diamonds), from the GISS GCM (triangles), and from the data of DSS PICO87 (asterisks). 


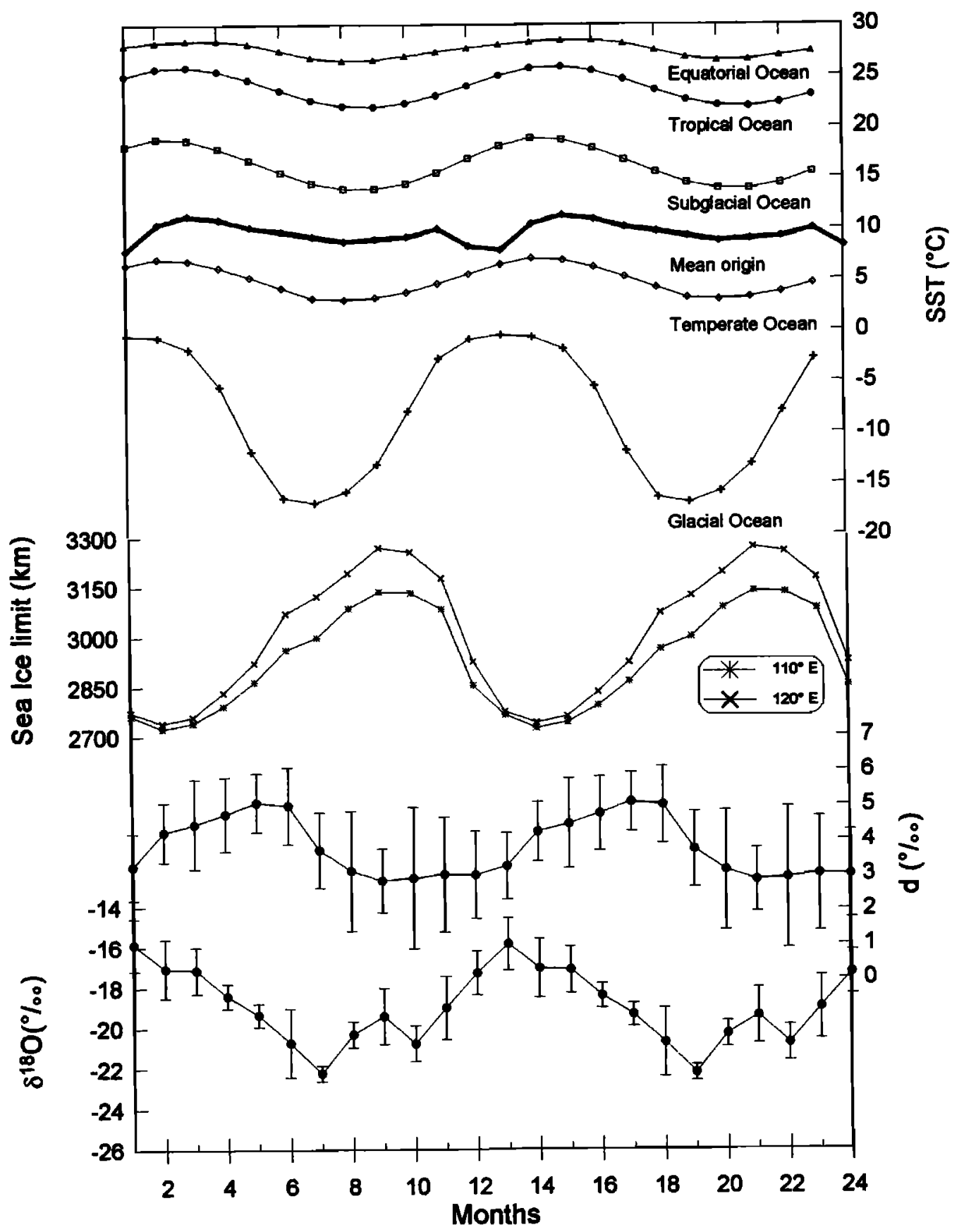

Figure 5. Deuterium excess and $\delta^{1 k} \mathrm{O}$ seasonal cycles as simulated by the GISS AGCM. The error bars illustrate the model interannual variability. On the top of the figure the seasonal sea surface temperature (SST) changes for the five possible precipitation sources of the Law Dome are represented (see caption of Figure 7 for the source zone definition). The seasonal cycle of the sea ice offshore Law Dome, at $110^{\circ} \mathrm{E}$ and $120^{\circ} \mathrm{E}$ averaged between 1979 and 1992 is also reported. The maximal distance to the coast (in kilometers) indicates the sea ice extent. Its interannual standard deviation is typically $50 \mathrm{~km}$.

of too warm local surface temperatures $\left(2.5^{\circ} \mathrm{C}\right.$ higher than observed) and an overestimation of their seasonal amplitude $\left(30^{\circ} \mathrm{C}\right.$ versus $16^{\circ} \mathrm{C}$ observed). Genthon [1994] has related this climatic bias to the surface snow albedo parameterization. The phasing of the GCM surface temperature and $\delta^{18} \mathrm{O}$ seasonal cycle is, however, in good agreement with the observations (Figure 4). Although slightly too high on average $(5.0 \%$ versus $3.8 \%$ observed). the simulated excess seasonal cycle emerges as a two step function with high values during autumn (between February and May) and low values during the rest of the year. The interannual variability is large during the first 6 months (typically 1-2\%o) and weaker during the last 6 months (lower than $0.8 \%$ ), in fair agreement with the observations (Figures 4 and 5). Within this large interannual variability the simulated seasonality is similar to the one obtained from isotopic measurements (3-4 months phase shift between $d$ and temperature).

Law-Dome-simulated precipitation originates mainly| from 
the Indian Ocean sector and is transported poleward by the zonal circulation in the tropics and subtropics and then more longitudinally in the high latitudes (Figure 5). The subtropical, temperate, and southern oceans (see caption of Figure 5 for detailed definition) provide more than $80 \%$ of the simulated precipitation. Because of the ocean thermal inertia, each of these oceanic regions (moisture sources) is characterized by a SST seasonal cycle shifted with respect to southern insolation, with a temperature maximum in late summer-autumn and a minimum in late winter-spring. However, the seasonality of the moisture origin is dominated by the contribution of the local Southern Ocean which increases in summer (more than $35 \%$ of the total precipitation) and decreases in winter (less than 10\%), reflecting the sea ice seasonality (Figure 3).

To better understand the role of seasonal moisture origin (Figure 4) and the role of the seasonality at each moisture source on the isotopic signals, we have performed additional simulations with a simple isotopic model (mixed cloud isotopic model, MCIM) developed by Ciais and Jouzel [1994], following the Rayleigh-type distillation models of Dansgaard [1964], Jouzel and Merlivat [1984], and Merlivat and Jouzel [1979]. This simple model considers an isolated air mass moving polarward from a prescribed water evaporation source to a prescribed precipitation location and accounts for the cloud microphysics processes (Figure 3 ). The seasonality of the moisture source meteorological variables will only imprint the isotopic composition of the first evaporated moisture $\left(\delta_{0}\right)$. In principle, the MCIM should be forced by modern observations, which is not possible due to the lack of vapor isotopic composition measurements [Craig and Gordon, 1965]. It is therefore necessary to prescribe or parameterize $\delta_{0}$, which is one major source of uncertainties for the simple model results [Jouzel and Koster, 1996]. In a first approach, $\delta_{0}$ can be calculated from the oceanic climatic parameters by assuming a closed system and a local isotopic balance between the precipitation and the evaporation (the so-called closure equation [Merlivat and Jouzel, 1979]). Alternatively, the $\delta$ simulated by an isotopic AGCM can be prescribed to the simple model, since the AGCM computes the exchange processes taking place at the ocean-atmosphere interface [Jouzel et al., 1997; Jouzel and Koster, 1996]. These two approaches have to be compared as they may lead to different $\delta_{\mathrm{n}}$ seasonal cycles.

The MCIM also has to be prescribed to the precipitation site temperatures; two approaches have been compared: using the Law Dome AWS observations (I. Allison, personal communication, 1997) or the GISS AGCM condensation temperatures. Altogether, four different simulations were performed for each month, each moisture source (five distinct sources): two approaches for the initial moisture (closure equation from observed SST and GISS relative humidity and wind speed versus GISS vapor isotopic composition) and two approaches for the site temperature (observed local inversion temperature versus GISS condensation temperature). Sensitivity experiments conducted with three other AGCM (LMD5.3, GISS II and ECHAM3) show that the initial isotopic composition $\delta_{0}$ calculated using the different AGCM outputs $(h, w)$ and the closure equation are almost independent of the GCM used [Delmotte, 1997]. For each of the four combined approaches, we obtain simulations of Law Dome isotopic seasonal cycles from each moisture source. Using the GISS mossture origin diagnostic (Figure 6), we also weigh the results from each mossture source by its monthly contribution (hereinafter referred to as mixed origin). This enables to separate the relative impact of the moisture source seasonal

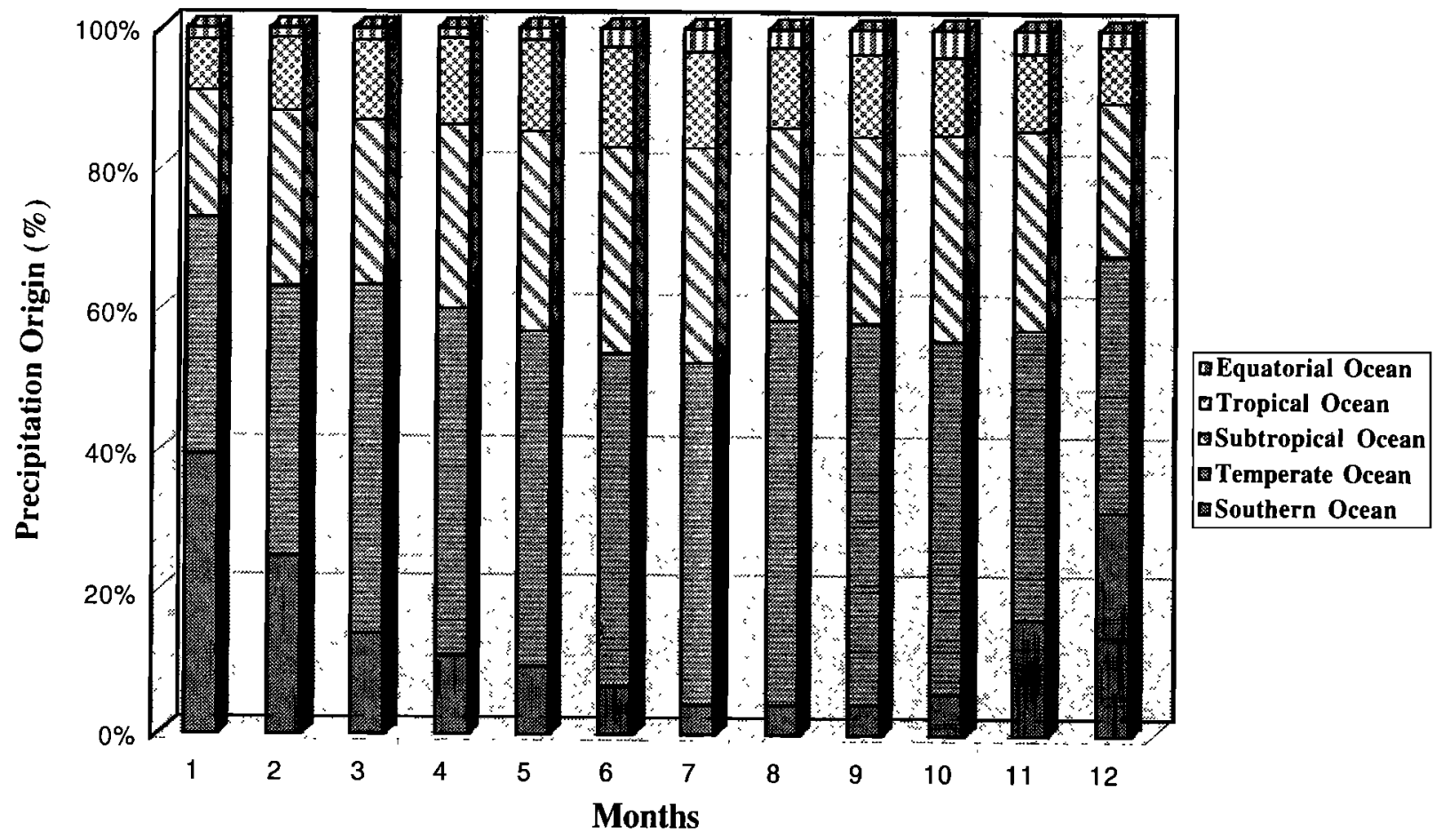

Figure 6. Monthly origin of the precipitation at Law Dome simulated by the NASAGISS AGCM. The standard deviation can be as high as 5 to $10 \%$ for southern, temperate, and subtropical origins during their relative maximum of amplitude. 

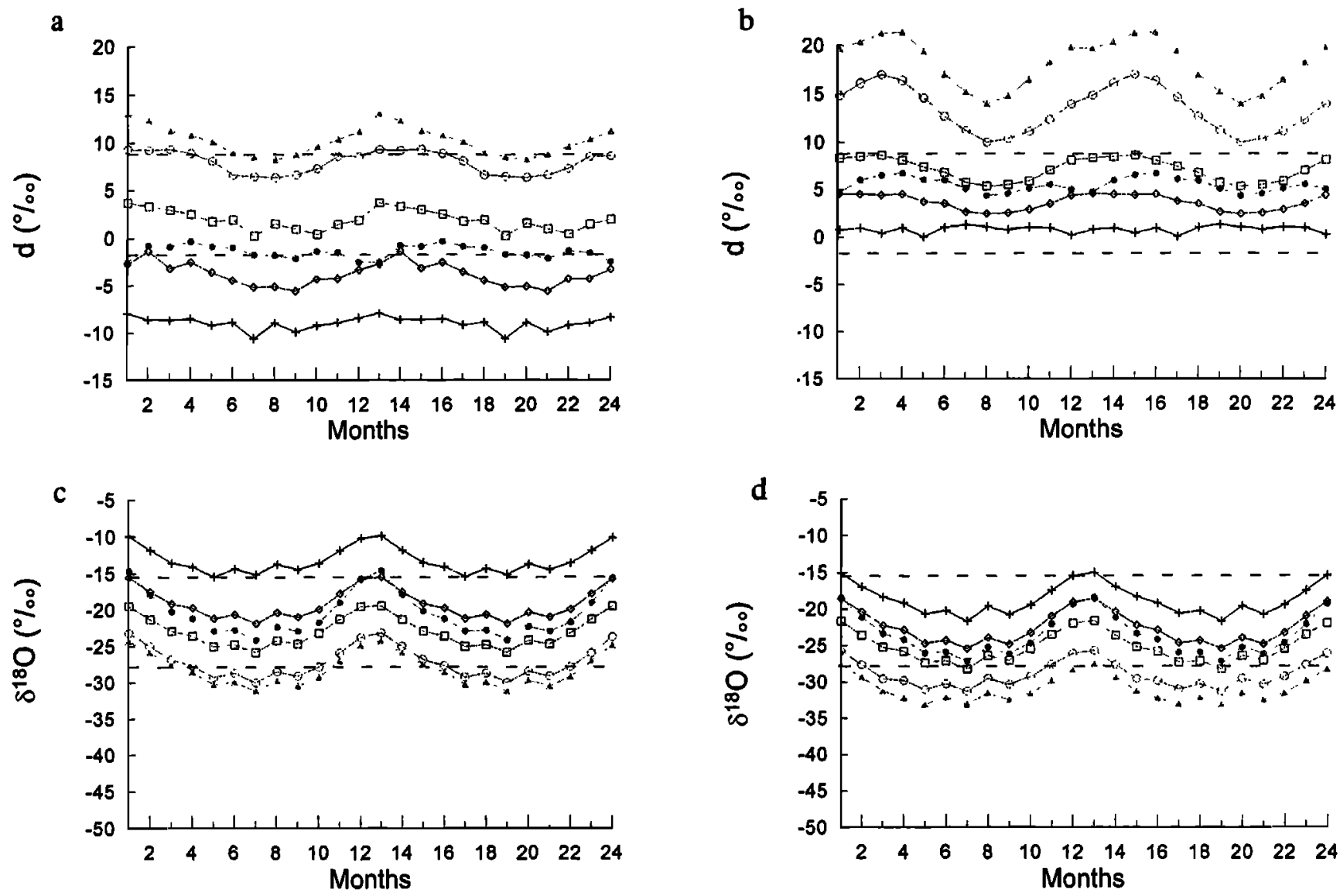

Figure 7. Simulations of the seasonal variations of $\delta^{18} \mathrm{O}$ and $d$ at DSS with the MCIM for various moisture origins when the initial vapor composition is taken from the GISS simulation (b, d) or calculated from the closure equation $(a, c)$. The different moisture sources were defined from latitudinal and SST considerations.

(1) Southern Ocean: crosses, latitude between $60^{\circ}$ and $75^{\circ} \mathrm{S}$, mean annual SST $<0^{\circ} \mathrm{C}$ (fixed to $-1.8^{\circ} \mathrm{C}$ between March and November); (2) temperate ocean: open diamonds, latitude between $45^{\circ}$ and $60^{\circ} \mathrm{S}$. mean annual SST between $-1^{\circ}$ and $12^{\circ} \mathrm{C}$; (3) subtropical ocean: open squares, latitude between $30^{\circ}$ and $45^{\circ} \mathrm{S}$, mean annual SST between $8^{\circ}$ and $22^{\circ} \mathrm{C}$; (4) tropical ocean: open circles. latitude between $15^{\circ}$ and $30^{\circ} \mathrm{S}$, mean annual SST between $20^{\circ}$ and $27^{\circ} \mathrm{C}$; (5) equatorial ocean: full triangles, latitude between $0^{\circ}$ and $15^{\circ} \mathrm{S}$, mean annual SST>24 ${ }^{\circ} \mathrm{C} ;(6)$ mixed origin: full circles, weighted moisture origin according to their relative contribution of Law Dome precipitation (compare Figure 6).

cycle from the impact of moisture origin, which cannot be done for the GCM.

When the MCIM is run with input parameters consistent with the GISS simulation (Figures $7 \mathrm{~b}$ and $7 \mathrm{~d}$ ), the resulting mixed origin isotopes show a phase relationship similar to the AGCM ( $\delta^{18} \mathrm{O}$ minimum in July and $d$ maximum in April). However, the annual mean value of $\delta^{18} \mathrm{O}$ is too low by $3 \%$, the excess too high by $0.5 \%$, and the amplitude of the $\delta^{1 x} \mathrm{O}$ seasonal cycle is overestimated by about $2.3 \%$ (one third). It is not possible to simulate exactly the results of the AGCM with the MCIM due to several factors: (1) the MCIM does not take into account the convective processes that are important in the vicinity of Law Dome due to the storm track trajectories and the relatively low latitude of this site in Antarctica; the AGCM simulates a strong contribution of the convective scheme to the precipitation and a strong isotopic signature of this convective activity (not shown); (2) the MCIM does not take into account the trajectories of the air mass and is run with a direct zonal idealized moisture transport; (3) the MCIM is run from monthly mean values without variability, for surface characteristics averaged over each oceanic zone, and does not aim at simulating individual precipitating events as the AGCM; (4) large uncertainties exist in the initialization of the MCIM in the partly sea ice-covered regions (Southern Ocean at freezing temperature), and (5) the MCIM microphysical parameterizations are different from the AGCM ones (same supersaturation function but different precipitation schemes). Taking into account the observed site temperature versus the GISS-simulated temperature only leads to an offset in the isotopic mean values (not shown).

The MCIM simulates a maximum in excess between March and April for each moisture source; the mixed source seasonal cycle therefore directly reflects the seasonal cycle of each individual moisture source (Figures $7 \mathrm{a}$ and $7 \mathrm{c}$ ). Depending on the MCIM inputs. one single moisture source (temperate or subtropical) can explain the observed mean values and phase relationships of the Law Dome isotopes. Indeed, the temperate and subtropical regions (annual mean SST between -1 and $+22^{\circ} \mathrm{C}$ ) provide $70 \%$ of Law Dome precipitation in the GISS AGCM simulation. 
However, using the closure equation to initiate the isotopic composition of the first vapor has a large impact on the model results and leads to very low and unrealistic $d$ values for the mixed origin (negative annual mean $d$ in Law Dome precıpitation). Moreover, the seasonal cycle of $d$ from each individual moisture source is this time much weaker and is for most sources maximum in January. No single moisture source can provide isotopes consistent with Law Dome observations. The realistic mixed origin seasonal cycle, in this case, does not result from the individual moisture source cycle but from the seasonality of moisture origin (Figure 7).

The combined use of the MCIM and the AGCM assists in understanding the mechanisms responsible for the phase relationship between the different isotopic species at Law Dome. The phase shift seems to be principally governed by the SST seasonal cycle and the seasonal contribution of coastal ocean and is consistent with the simulated origin of the precipitation. However, we think that getting a full benefit from the phase shift information will require the use of highresolution models. For instance, the GISS AGCM simulates similar isotopic seasonalities in Law Dome and D47 regions, disagreeing with D47 observations. At this location, local meteorological conditions (strong katabatic winds) may disturb the snow stratigraphy but also prevent the transport of moisture from the closest ocean (H. Gallée, personal communication, 1998). No state-of-the-art AGCM is, however, able to simulate coastal Antarctic katabatic winds which are strongly constrained by the coastal ice sheet topography.

\section{Conclusion}

We use the high-resolution deuterium excess (d) and $\delta^{18} \mathrm{O}$ data, which can be obtained from high accumulation sites near the summit of Law Dome to show the distinct seasonal behavior of $d$ compared with $\delta^{18} \mathrm{O}$. While the $\delta^{14} \mathrm{O}$ clearly reflects the local temperature [Van Ommen and Morgan, 1997]. the $d$ cycle is shifted by four months with respect to the $\delta^{1 x} O$ and this local temperature. The GISS AGCM is able to simulate crudely the main characteristics of the Law Dome climate and shows a dominant marine influence, with moisture arriving mainly from local to subtropical oceans in the Indian Ocean sector. As confirmed by studies with a simple isotopic model, the seasonality of the deuterium excess reflects the seasonal cycle of the Southern Ocean surface temperatures. combined with the seasonality of the local ocean influence when ice free. Although aerosols can influence the precipitation processes (as nucleation support for droplet formation) and might also have an impact on the corresponding iractionation processes [Hoffinann et al., 1998]. their role on the cloud microphysics is not taken into account for the modeling of the water isotopic cycle. Nonetheless, we cannot rule out a possible role of the aerosols on a seasonal timescale as their measurements at Law Dome exhibit a strong seasonal cycle [Curran et al., 1998].

The strong seasonality of the contribution of the Southern Ocean has an imprint on the $\delta^{10} \mathrm{O}$ seasonal cycle. The AGCM indicates that during local winter the sea ice inhibits input from the Southern Ocean thus increasing the relative contribution of more remote oceanic sources; these more remote sources bring to Antarctica moisture characterized by low $\delta^{18} \mathrm{O}$ values (results from the MCIM). On the contrary, during local summer the larger contribution of the local ocean results in higher $\delta^{18} \mathrm{O}$ values. In other words, the seasonal cycle of $\delta^{18} \mathrm{O}$ clearly reflects the local temperature at Law Dome but also includes a $10-20 \%$ enhancement due to modulation of the Southern Ocean contribution to the moisture supply through its sea ice cover. Such a factor could partly explain the difference between the spatial and the seasonal isotopetemperature relationships [Van Ommen and Morgan, 1997].

A study devoted to seasonal cycles of $\delta^{18} \mathrm{O}$ measured along the DSS deep ice core and covering the past 700 years [Morgan and Van Ormmen, 1997] has evidenced a clear change in the seasonal patterns of local temperatures during this recent period. The major climatic variations arise from significant fluctuations in winter temperatures with warmer winters between AD 1400 and 1500 and colder winters in the early 1800s (European Little Ice Age). The mechanisms of climate change involved in such recent fluctuations are still unknown, especially because few proxy data are available for the subtropical to high-latitude oceans at temporal resolution lower than 1000 years. Previous studies devoted to the deuterium excess in Antarctica have been performed on a much longer timescale (glacial to interglacial changes [Jouzel et al., 1982; Vimeux et al., 1999] on ice from deep drillings in the central plateau (Vostok, Domes B and C). However, none of these ice cores provided subseasonal resolution deuterium excess records which could be calibrated with isotopic models for present day. Interestingly, the deep DSS core enables a continuous $d$ study of the Holocene period (with a high resolution) but also covers the last climatic transition and the last glacial period (bottom $80 \mathrm{~m}$ of the core). Preliminary results for the deuterium excess profile measured at a yearly resolution along the deep core show well-organized and significant fluctuations in the recent past, as well as a deuterium excess increase by about $5 \%$ between the last glacial period and the Holocene level [Delmotte, 1997], in agreement with the records at more central locations (Vostok, Domes $\mathrm{B}$ and $\mathrm{C}$ ). We show from the present study that combining measurements of $\delta^{18} \mathrm{O}$ and $\delta \mathrm{D}$ to obtain a record of deuterium excess at subseasonal resolution could provide information on Southern Ocean surface characteristics and therefore could help understanding the mechanisms of climate change encountered during the late Holocene period.

Acknowledgments. Experimental and computing facilities were provided by CEA. Financial support was also recelved from the INSTN as a thesis grant for M.D. We thank all participants to the drilling and processing of the shallow cores used in this study. We thank the GISS for enabling us to use their AGCM, Rıck Healy for the computing support, and Gilles Delaygue for fruitful interaction with the model. We also thank Neal Young for ice core samples, Jo Jacka for the sea ice data and Ian Allison for the AWS data. We are very indebted to the two reviewers whose comments and suggestions helped clarify and improve this manuscript. This is contribution 312 of LSCE.

\section{References}

Allison, I., G. Wendler, and U. Radok, Climatology of the East Antarctic ice sheet $\left(100^{\circ} \mathrm{E}\right.$ to $\left.140^{\circ} \mathrm{E}\right)$ derived from automatic weather stations., I. Geophys. Res., 98, 8815-8823, 1993.

Budd, W. F., and V. I. Morgan, Isotopes, climate and ice sheet dynamics from core studies on Law Dome, Antarctica., m UGGI, edited by IAHS, pp. 312-321, IAHS, Grenoble, 1977.

Budd, W.F., Glaciological studıes in the region of Wilkes, eastern Antarctica, 1961, Antarct. Div., Melbourne, Australia, 1966.

Crais, P., and J. Jouzel, Deuterium and oxygen 18 in precipitation: [sotopic model, including mixed cloud processes., / Geophys. Res, 99 , 16,793-16,803, 1994. 
Ciais, P., J. Jouzel, J.R. Petit, V. Lipenkov, and J.C.W. White, Holocene temperature variations inferred from six Antarctic ice cores, Ann. Glaciol., 20, 427-436, 1994.

Ciais, P., J.W.C. White, J. Jouzel, and J.R. Petit, The origin of present day Antarctic precipitation from surface snow deuterium excess data, I. Geophys. Res., 100, 18,917-18,927, 1995.

Craig, H., and L.I. Gordon, Deuterium and oxygen 18 variations in the ocean and the marine atmosphere, in Stable lsotopes in Ocennographic Studies and Paleotemperatures, pp. 9-130, Cons. Natl., delle Ric., Lab. di Geol. Nucl. Pisa, Spoleto, Italy, 1965.

Cuffey, K.M., and G.D. Clow, Temperature, accumulation, and elevation in central Greenland through the last deglacial transition, J. Geopllys. Res., 102, 26,383-26,396, 1997.

Curran, M., T. Van Ommen, and V. Morgan, Seasonal characteristics of the major ions in the high accumulation DSS ice core, Law Dome, Antarctica, Ann. Glaciol., 27, 385-390, 1998.

Dansgaard, W., Stable isotopes in precipitation, Tellus, 16, 436-468, 1964.

Delaygue, G., V. Masson, J. Jouzel, and R. Koster, The origin of Antarctic precipitation: A modeling approach, Tellus, ser. B, 52, In Press.

Delmotte, M., Enregistrements climatiques à Law-Dome: Variabilité pour les pénodes récentes et pour la déglaciation, Ph.D. thesis, Univ. Joseph Fourier, Grenoble, France, 1997.

Delmotte, M., D. Raynaud, V. Morgan, and J. Jouzel, Climatic and glaciological information inferred from air content measurements of the Law Dome ice core, East Antarctica, J. Glaciol., 45 (150), 255-263, 1999.

Fisher, D.A., Remarks on the deuterium excess in precipitation in cold regions, Tellus, ser. B, 43, 401-407, 1991.

Fisher, D.A., N. Reeh, and H.B. Clausen, Stratigraphic noise in time series derived from ice cores, Ann. Glaciol., 7, 76-83, 1985.

Genthon, C., Antarctic climate modeling with general circulation models of the atmosphere, J. Geopli1/s. Res., 99 , 12,953-12,961, 1994.

Hansen, J.E., G. Russell, D. Rind, P. Stone, A. Lacis, S. Lebedeff, R Ruedy, and L. Travis, Efficient three-dimensional global models for climate studies: Models I and II, Mon. Weather Rev., 111(4), 609-662, 1983.

Hoffmann, G., M. Stievenard, J. Jouzel, J.W.C. White, and , S.J. Johnsen, Deuterium excess record from central Greenland, modeling and observations, in lsotope Teclniques in the Study of Environmental Clunnges, pp. 591-602, Int. At. Energy A, , 1998

Johnsen, S., W. Dansgaard, and J. White, The origin of Arctic precipitation under present and glacial conditions, Tellus, ser. $B$, $41,452-468,1989$.

Jouzel, J., and R.D. Koster, A reconsideration of the initial conditions used for stable water isotope models, J. Geophys. Res.,101, 22,933-22,938, 1996.

Jouzel, J., and L. Merlivat, Deuterium and oxygen 18 in precipitation: Modeling of the isotopic effects during snow formation, J. Geophys. Res., 89, 11,749-11,757, 1984.

Jouzel, J., L. Merlivat, and C. Lorius, Deuterium excess in an east Antarctic ice core suggests higher relative humidity at the oceanic surface during the last glacial maximum, Nature, 299, 688-691, 1982

Jouzel, J., C. Lorius, J-R. Petit, C. Genthon, N.I. Barkov, V.M. Kotlyakov, and V.M. Petrov, Vostok ice core: A continuous isotope temperature record over the last climatic cycle $(160,000$ years), Nature, 329 (6138), 403-408, 1987a.

Jouzel, J., G.L. Russel, R.J. Suozzo, R.D. Koster, J.W.C. White, and W.S. Broecker, Simulations of the HDO and $\mathrm{H}_{2}{ }^{18} \mathrm{O}$ atmospheric cycles using the NASA GISS general circulation model: Seasonal cycle for present-day conditions, J. Geophys. Res.,92, 14,739-14,760, 1987b.

Jouzel, J., R.D. Koster, R.J. Suozzo, G.L. Russell, J.W.C. White, and W.S. Broecker, Simulations of the $\mathrm{HDO}$ and $\mathrm{H}_{2}{ }^{14} \mathrm{O}$ atmospheric cycles using the NASA GISS general circulation model : Sensitivity experiment for present day conditions., J. Geophys. Res., 96, 7495-7507, 1991.

Jouzel, J., R. Koster, and S. Joussaume, Climate reconstruction from water isotopes: What do we learn from isotopic models?, in Climntic Variations and Forcing Mechanisms of the Last 2000 Years, edited by P. D. Jones, R.S. Bradley, and J. Jouzel, pp. 213241, Springer-Verlag, New York, 1996.

Jouzel, J., et al., Validity of the temperature reconstruction from water isotopes in ice cores, J. Geophys. Res., 102, 26,471-26,487, 1997.

Koster, R.D., J. Jouzel, R. Suozza, G. Russell, W. Broecker, D. Rind, and $P$. Eagleson, Global sources of local precipitation as determined by the NASA/GISS GCM, Geophys. Res. Lett.,13(1), 121-124, 1986.

Koster, R.D., J. Jouzel, R.J. Suozzo, and G.L. Russell, Origin of July Antarctic precipitation and its influence on deuterium content: A GCM analysis., Clim. Dyn., 7, 195-203, 1992.

Merlivat, L., and J. Jouzel, Global climatic interpretation of the deuterium-oxygen 18 relationship for precipitation., f. Geophys. Res., 84, 5029-5033, 1979.

Morgan, V.I., Oxygen isotope analysis of Antarctic snow and ice, M.Sc. thesis, Univ. of Melbourne, Victoria, Australia, 1979.

Morgan, V.I., An oxygen isotope-climate record from the LawDome, Antarctica, Clim. Change, 7, 415-426, 1985.

Morgan, V.I., and T. Van Ommen, Seasonality in Late Holocene climate from ice core records, Holocene, 7(3), 351-354, 1997.

Morgan, V.I., C.W. Wookey, J. Li, T.D. Van Ommen, W. Skinner, and M.F. Fitzpatrick, Site information and initial results from deep ice drilling on Law Dome, J. Glaciol., 43(143), 3-10, 1997.

Neftel, A., P. Jacob, and D. Klockow, Long term record of $\mathrm{H}_{2} \mathrm{O}_{2}$ in polar ice cores, Telluss, ser. B, 38 (3-4), 262-270, 1986.

Neftel, A., R.C. Bales, and D.J. Jacob, $\mathrm{H}_{2} \mathrm{O}_{2}$ and $\mathrm{HCHO}$ in polar snow and their relation to atmospheric chemistry, in Ice Core Studies of Global Biogeochemical Cycles, edited by R.j. Delmas, pp. 249-264, Sprınger-Verlag, New York, 1995.

Petit, J.R., J.W.C. White, N.W. Young, J. Jouzel, and Y.S. Korotkevich, Deuterium excess in recent Antarctic snow, $J$ Geophys. Res.,96, 5113-5122, 1991.

Russell-Head, D., and I. Simmonds, Temporal structure of surface weather parameters at Casey, Davis, Mawson and Macquarie Island, Technical report 35, Univ. of Melbourne, Sch. of Earth Sci., Melbourne, 1993.

Van Ommen, T.D., and V. Morgan, Peroxide concentrations in the Dome summit south ice core, Law Dome, Antarctica, $J$. Geophrys. Res.,101, 15,147-15,152, 1996.

Van Ommen, T.D., and V. Morgan, Calibrating the ice core paleothermometer using seasonality, J. Geophys. Res., 102 , 93519357, 1997.

Vaughn B.H., J.W.C., White, M. Delmotte, M. Trolier, O. Cattani, and $M$. Stiévenard, An automated system for hydrogen isotope analysis of water, Cliem. Geol., 152(3-4), 309-319, 1998.

Vimeux, F., V. Masson, J. Jouzel, M. Stievenard, and J.R. Petit, Glacial-interglacial changes in ocean surface conditions in the Southern Hemisphere, Nature, 398, 410-413, 1999.

White, J.W.C., L.K. Barlow, D.A. Fisher, P.M. Grootes, J. Jouzel, S.J. Johnsen. M. Stuiver, and H. Clausen, The climate signal in the stable isolopes of snow from Sunmmt, Greenland: Results of comparisons with modern climate observations, J. Geophys. Res.. 102, 26.42526.439. 1997

M. Delmotte. Laboratoire de Géochimie et Cosmochimie, CNRS/IPGP. 4. place Jussieu, Tour $143^{\mathrm{imh}}$ Etage, 75252 Paris Cédex 05, France. (delmotte@ipgp.jussieu.fr)

V. Masson and J. Jouzel, Laboratoire des Sciences du Climat et de l'Environnement (LSCE), UMR CEA-CNRS 1572, l'Orme des Merisiers, C.E.A. Saclay, 91191 Gif-sur-Yvette Cédex, France. (masson(ailsce.saclay.cea.fr. jouze)@lsce.saclay.cea.fr).

V. I. Morgan, Antarctic CRC and Australian Antarctic Division, Box 252-80, Hobart 7001, Australia. (vin.morgan@utas.edu.au).

(Reccived November 10, 1998; revised October 6. 1999; accepted October 12, 1999.) 